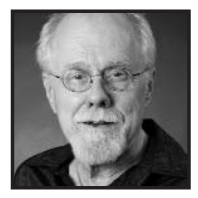

\title{
Commentary:
}

\section{Off the Diving Board: From Poetry Into Literacy} John Warren Stewig, Carthage College

\section{ABSTRACT}

Ours has become, in the United States, an era when evaluation of school success: of students, teachers, and entire systems, has devolved into derivative fact-emphasizing paper-and-pencil tests. Each of these components suffers from such limited evaluation. Teachers, administrators and policy makers need to assert that a literacy program cannot be successful unless it is evaluated to highlight a wide variety of problem-setting and problem-solving processes, many of which cannot be measured exclusively on paper.

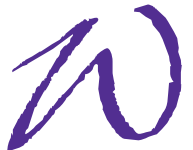

riting this was a poetic challenge, not in the language that I produced, but in that the specified limit was 2000 words. That is brief compass indeed, but parallel to what poets do. Poets routinely compact images and distill language, to elicit response.

The assertions on which this piece is based are not surrounded here by extensive citations, though the literature is full of such sources. When Edward Lear asserts in "The Owl and the Pussycat" (2007) that the two "ate with a runcible spoon," there was no need to provide supportive data that such a thing exists, though in fact the etymology of that object is quite interesting.

These assertions/assumptions are certainly not universally accepted. Yet they lead me to a central question. Is being "educated," and "literate" more than simply being able to answer questions written by other people, accurately, at a particular time decided upon by someone other than the answerer? For some people, doing 
this task is indeed a sign of an educated, literate person. Instead, l'd like to suggest that if we want to develop literate children, we must provide different ways to determine if we have accomplished the task.

For me, literacy is evident when children use their imaginations to create something new, which does not happen on a schedule, and does not always (or indeed often) fit easily into what ever standardized measures are the soup de jour.

What l'd like to do here is use a single edition of a poem, "The Owl and the Pussycat" by Edward Lear, and base what follows on that. My purpose is to show how it might be used with a group of children to develop myriad literacy skills, more sophisticated, and hence more usable in real, adult life, than questions like, "Where did the cat and owl get the wedding ring?" or "What two foods did they eat after they married?"

\section{Listening}

One such literacy skill is listening. We want children to listen to the teacher, not just to follow directions but to revel in the "flow of speech sound through time." Beautiful sound, more imaginative than the utilitarian speech which serves us well enough in ordinary everyday interactions. We develop listening skills by reading interesting things to children: poetry, fiction, nonfiction, plays. We read, having rehearsed what we will read, so we can shape the sounds: articulating unfamiliar words and making the sentences into music. How can we emphasize the variety of sentence patterns the skillful author uses? By making sure we take time to read aloud to ourselves in preparation. This is obviously easier with a four-line poem selected to open the school day, than for the ten-page chapter we use to settle the class after lunch.

We provide time for children to listen to themselves, as they partner and read something they have enjoyed with another child in the classroom. Never mind if the reading isn't as fluent as when the teacher reads - it is the process which is important. It's a shared experience, "I like this so I want to read it to you."

Listening to other children, beyond the home classroom, is also important. One of the glories of the one-room school was the interaction of younger with older and the reverse. Going forth into a different environment, even if just across the 
hallway, is an adventure. Not all children will enjoy it at first, but it can build confidence for all children when the process is skillfully managed by the teacher.

\section{Speaking}

Children need to talk to discover what they know, what they believe, and to wonder about unknown parts of the world. Talking to answer someone else's questions is only a small part of becoming fluent in speaking.

Recasting from a piece read aloud into their own language is important. How could students retell a poem or a story using their own words to capture a listener? With very young children this needs to take place in the context of a more experienced scribe, an older child or perhaps a class aide. With older children, recording with a machine lets them reflect on their own voice quality. Discovering the process of recapturing the people and events in something they have heard into their own language can be reinforcing for children.

\section{Storytelling}

Beyond retelling, children need experience with creating from "scratch" (i.e, making up characters they care about doing things they find interesting, scary, or in other ways compelling to them). We need not be concerned that some will take to this more easily than others. Putting children in small groups so they can spin a story line for only one or two other listeners, can move into slightly larger telling/listening groups as the teacher observes the time is right.

\section{Choral Reading}

One of the saddest losses in our push to measure everything that happens is this very old art of using voices together to intrigue an audience. The Greek playwrights used chorus groups because reading literacy was uncommon. We can use it for the aesthetic purpose of working on important qualities of oral language: pitch, stress, and juncture to present a poem or a longer piece of prose to delight an 
audience. Important social skills can develop as the teacher guides the group to decide who will say what, and how.

\section{Dramatizing}

Until the middle of the last century, important experiences in dramatizing were going on in schools. Not simply formal drama (i.e., the scripted play), but more casual though directed experiences of building a character and a plot done right in the classroom with no written script at all. Unfortunately this happens less often now, simply because it can look too disorganized to an outside observer. Skillful teachers can help children decide what they will make a classroom drama about, and who the characters are that will enact that drama. A long line of drama practitioners have written about their techniques so that inexperienced teachers can find helpful direction. A more challenging task for teachers who want to do drama is to understand, and be able to talk about the myriad benefits such drama experiences provide.

\section{Reading}

My approach to this particular literacy skill, whether writing about it now, or in previous years spent working directly with children, is to remain aware that ideas of when and how to teach reading vary greatly around the world. In the United States we are currently caught up in a "basic" skills mania, which emphasizes using prepared commercial materials that will pull children up to a certain level of prescribed accomplishment in a specified amount of time. In so doing, we ignore that, for instance, in the Scandinavian countries and elsewhere, children are not taught to read until they are seven years old.

An alternative to current approaches would be to immerse students in the model of fluent, adult, standard language as available in children's books. Seeing an adult enjoy reading is one of the most critical factors in encouraging children to want to read. Not all children come from homes in which they see such adult models. Making a commitment to read aloud daily to children, at a particular time and for a particular allotment of time, is critical. It is interesting that years after college students have left my classes, one thing a majority remember and remark upon is the reading aloud I did in every session. 
We provide regularly scheduled opportunities for children to use their developing reading skills to read to others. Certainly there is a ten-minute block in any class day to let students read to their partner. When an acceptable skill level is reached, those who are willing to volunteer should be able to sign up to read to other listeners via the school intercom system. What an amazing outcome would result with a "Poem a Day" practice, reaching to every child in the school.

\section{Writing}

Children write a lot in schools, but it is mostly writing from outside the experience. Rewriting as if one of the characters involves children not in writing "about" but rather writing "as if." It is always interesting to ask children questions like: "What did the cat feel as she was serenaded by the owl?" In the poem, the owl "sings" but the teacher as oral vocabulary model, purposely uses an alternative like serenaded."Why would the pig be willing to sell his ring?" This sort of question stimulates thinking, rather than searching for a particular answer.

It is always profitable to stimulate thinking by extending in either way beyond the poem. What happened before, and/or what happened after? We could ask, for instance, "How did the cat meet the owl?" "When they sailed away, who did they leave behind?" "After they finished dancing, where did they live?"

\section{Visual Literacy}

In all types of literacy, we are concerned with helping children receive messages, evaluate, and create their own messages in response. In an increasingly visual world, where messages arrive with increasing speed, we help children become visually competent by using the art in picture books. We move through stages in which we ask children to

DESCRIBE what they see;

COMPARE what they see to something else they have seen; and VALUE, which they prefer. 
We start with picture books including art that is easy to respond to. But then we move to art in which the illustrator challenges the viewer. The art in the version I'm using, by Stéphane Jorisch (Lear, 2007), isn't easily anticipated. That is both the challenge and eventually the delight of this art, as children come to experience what the illustrator has created on the page. In a small format $\left(5^{1 / 4}\right.$ " $\mathrm{h}$ by $\left.10{ }^{1 / 2}{ }^{\prime \prime} \mathrm{W}\right)$, unusual in picture books, the artist begins with "O let us be married" on a translucent sheet before a couple shown on the following page, which isn't the owl and cat. Why? The reason isn't clear, though the two main characters appear (heads only) on the title page. Four double wordless spreads-in watercolor sharpened with fine pen line, show eccentric landscapes finally leading to the first text page. Again, why? There's lots to speculate on here, and throughout the book.

The art by Beck (Lear, 1996) and by Knight (1983) are more easily understood, and for most children, probably easier to respond to. Beck's watercolors are heavily crosshatched in naturalistic colors and the owl and cat do not appear in human clothing. His double-page spread showing the passage of time and varying weather is clever. Knight's whimsical art sets the poem in the frame of an eccentric professor who beguiles two children with the tale. They are transformed into the cat and owl, wearing human clothes in a rococo fantasy land.

\section{Conclusion}

There are two caveats about this approach. First, I would never do all of these things with one poem, or one class. Overkill is too easy, as we see in many commercial literacy programs. No poem should be so burdened with "activities" that children, even if they are becoming more literate, never want to return to that particular poem again. Second, there are so many things to do with any one class, that there needs to be a balance between literacy-driven activities and other experiences. Helping children swim around in a sea of poetry will certainly ensure that when they climb out, they will be more literate adults. 


\section{References}

Knight, H. (1983). Hilary Knight's the owl and the pussy-cat. New York: Simon and Schuster.

Lear, E. (1996). The owl and the pussycat. Art by Ian Beck. New York: Atheneum. (Original work published in 1871)
Lear, E. (2007). The owl and the pussycat. Illustrated by Stéphane Jorisch. University of Toronto Press: Kids Can Press. (Original work published in 1871)

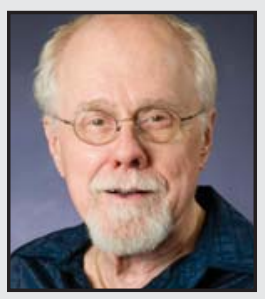

John Warren Stewig, Director of the Center for Children's Literature, Carthage College, Kenosha (WI, USA) taught creative drama, language arts, and children's literature at the university level, after a career as an elementary school teacher. He did speeches and workshops with teachers and librarians in twenty-six states and two provinces of Canada while writing fourteen books for teachers/librarians, as well as eleven books for children, which reflect these experiences.

\section{LINK TO:}

http://faculty.carthage.edu/jstewig 